\title{
DETERMINATION OF PROPERTIES OF E-B DIESEL FUELS
}

\author{
Fatih AYDIN ${ }^{* 1}$ Hüseyin ÖĞÜT ${ }^{2}$ \\ 1. Selçuk University, Technical Science College, 42130 Konya / Turkey \\ 2. Selçuk University, Faculty of Agriculture, 42130 Konya / Turkey
}

\begin{abstract}
In this study, biodiesel production was realized by converting raw oil obtained from safflower seed to Safflower Oil Methyl Esther (Safflower Biodiesel) by means of raw oil extraction with heating at $90{ }^{\circ} \mathrm{C}$ and pressing after Vals process and consequently transesterification process followed raw oil extraction. Experimental fuels were obtained as in $M_{100}$ $E_{2.5} B_{2.5} M_{95}, E_{5} B_{5} M_{90}, E_{5} B_{2.5} M_{92.5}$ and $E_{2.5} B_{5} M_{92.5}$ forms by mixing biodiesel fuel obtained from safflower with diesel fuel and bioethanol additives at a ratio of $2.5 \%$ and $5 \%$ and by mixing in volumetric ratio according to inversely proportion. Fuel properties of diesel fuel and the obtained fuel mixtures were determined with following tests; Kinematic viscosity, Density, Water content, $\mathbf{P H}$ values, Color determination, Heating value, Flash point, Cloud, Pour and Freezing points, Copper rod corrosion test, Iodine number, CFPP (Cold Filter Plunge Point) and Cetane number tests. Finally, the fuel properties of E-B Diesel were found suitable with standards.
\end{abstract}

Keywords: Safflower, bioethanol, biodiesel, transesterification, fuels.

\section{INTRODUCTION}

Energy is an indispensable part of human life. Besides, energy consumption per person is among the indicators of development of a country. Supplying energy in a steady, sufficient and safe manner and increasing efficiency along with effectiveness through processes for energy procurement is a must in order to support socioeconomic growth and continue sustainable development [27].

There are three main routes for the countries in order to keep energy sources persistent. First and the primary one is detecting its own resource potential accurately and converting this resource to energy in the most appropriate way by improving it. Second one is to be able to acquire control over necessary resources and their transport routes and means for energy production via participating international resource search and exploiting activities in the abroad with national companies and having share in these resources. For the cases that the first two routes are insufficient or for the cases that need action for strategic-economic measures, third route is tending towards short, medium and long term imports. When import is deemed to be a necessity, one of the most important points is diversifying suppliers and resources [26].

Fuels that countries gather from their own herbal and animal resources are briefly called biofuels. Biofuels contains all sorts of liquid and gas fuels originating from herbal and animal resources. Alternative fuels such as biogas, bioethanol, biomethanol and biodiesel are in the range of biofuel definition. However bioethanol is the most commonly used one among biofuels [11]

Bioethanol is a biofuel that can be produced by means of fermentation of sweet and amylaceous plants or acidic hydrolysis of cellulosic mass. Plants such as sugar beet, sugar cane, corn, wheat, potato, woody plants such as stem, straw, shell, agricultural waste and residuals and,molasses that is side product of sugar production can be used as raw material [9].

The first method utilized in the bioethanol production was acid hydrolysis. Enzyme production method took place of this method in the following years. Historical development situation is given in figure 1 [19].

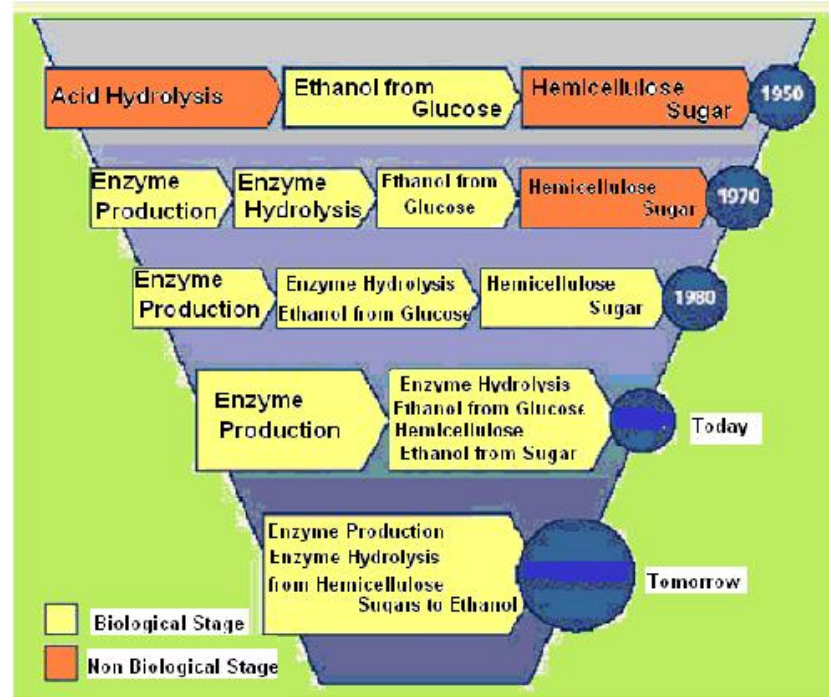

Fig. 1 Historical development of bioethanol production [19]

The biggest bioethanol producers in the world are USA and Brazil. For common usage of ethanol as fuel alcohol, USA, Austria, France, Switzerland, Brazil, India and Thailand can be given as instances. 2012 World bioethanol production was determined as 22.7 billion liter/year. Bioethanol production between 1975 and 2012 from all around the world is shown in figure 2 . 


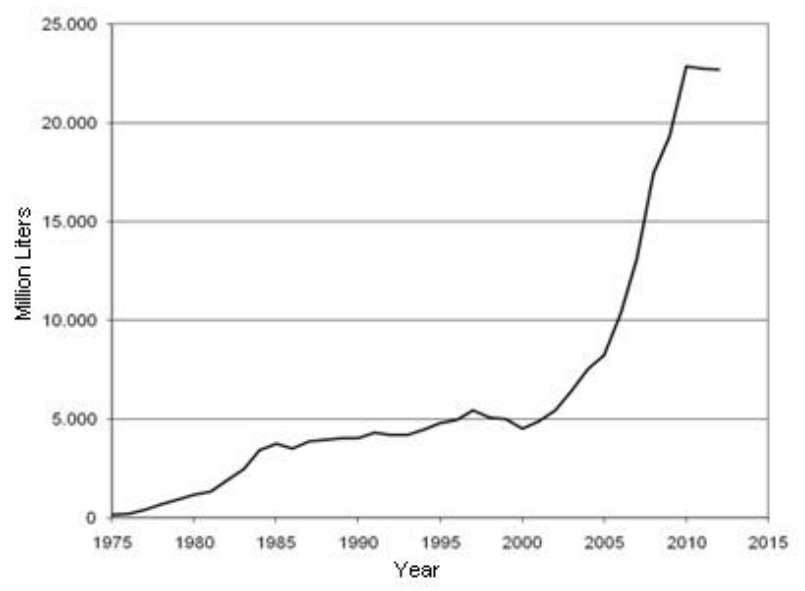

Fig. 2 World bioethanol production [2]

Cetane number of the fuel is important because fuels those can be easily self ignite and those decreases the ignition delay are preferred in diesel engines [10].

Solubility of bioethanol in diesel fuels is limited. Phase separation in bioethanol - diesel mixtures and water content of the mixture are important problems. Besides, cetane number of bioethanol is very low [16].

Heat content (heating value) of the mixture is reduced when bioethanol is added to diesel fuel [12].

These negative points can be overcome by means of biodiesel additives.

Biodiesel is oil acid methyl ester mixtures as described in TS EN 14213 and/or TS EN 14214 standards and which are produced from herbal and animal oils, oil wastes and residuals [13].

Flash point of biodiesel is higher than diesel fuel. This feature makes biodiesel a safer fuel in usage, transportation and storing. Biodiesel can be mixed with petroleum originated diesel fuel in every ratio and this characteristic can be used in order to increase the quality of petroleum sourced diesel fuel. It reduces emission values of hazardous gases occurred after combustion, increases lubrication amount of the engine [15].

The raw materials that biodiesel is produced from can be listed as; Safflower, canola, soybean, palm, sunflower, olive pomace (prina), mustard, other oily seeds and fruits, waste oil after frying, seeds of the fruits and animal fats [22]. Biodiesel cycle appears in figure 3 .

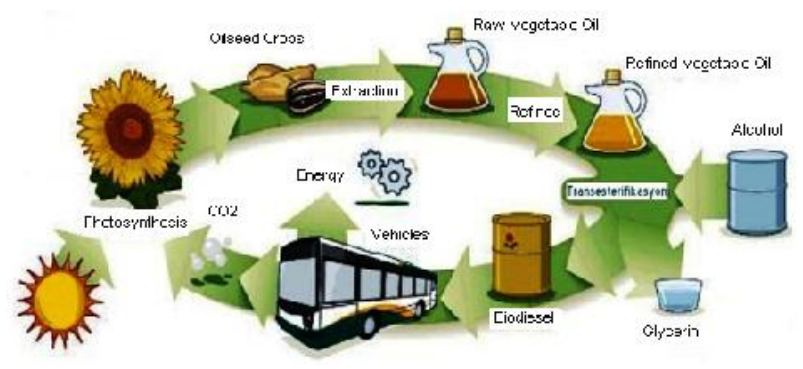

Fig. 3 Biodiesel cycle [3]

Although there are methods for biodiesel production, the most widespread one today is transesterification method. In the transesterification, oils from oily seeds of plants such as canola, safflower sunflower, soybean or animal fats are reformed by transesterification reaction together with a short chained alcohol (usually methanol or ethanol) with the help of a catalyst. The product is a liquid, environmentally friendly, renewable biofuel [14].

Transesterification reaction scheme is seen in figure 4 .<smiles>COC(=O)CC1OCCOC(O)O1</smiles>

Triglycerides Methanol

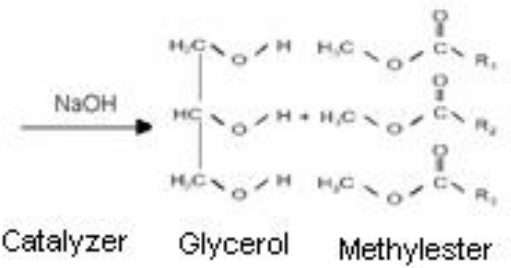

Fig. 4 Transesterification reaction of triglyceride with methanol [21]

Rudolf Diesel (1858-1913) tested his engine designed according to herbal oils and exhibited his engine using peanut oil as fuel in Paris World Exhibition in 1900 [18].

The topic lost its popularity due to the difficulties in direct usage of herbal oils as fuels and wide spread usage of petroleum products. However scientific studies on eliminating glycerin in the herbal oils in order to use them as fuels had kept going and the first patent was secured at 31 August 1937 by G.Chavanne from Bruxelles in Belgium for the fuel that we know as "Biodiesel" today. The petroleum crises at 1970s and 1990s speeded up search for alternative fuels and "Biodiesel" was taken into consideration again. There have been many incentive studies going on for biofuels and biodiesel in EU since 2003. Member countries were asked to state their national production and usage targets in their progress reports. They are utilizing "polluting one pays" criteria in their energy and tax politics. USA, which sees "safety of energy supply as a national safety element", targeting to compensate $25 \%$ of its energy consumption from renewable energy resources in 2025 with its " $25 \times 25$ " motto and developing projects for these aims, established its own system in the biodiesel subject too. Primarily they prepared ASTM-6751 standard applicable to soybean oil, which can be regarded as their national herbal oil. During 5\% biodiesel mixed B5 form of the fuel was sold in the fuel stations extensively, they ensured $100 \%$ utilization by providing tax privilege [5].

World biodiesel productions from 1985 to 2012 are shown in figure 5 .

Safflower is a one year, long day, oil plant that can be cultivated between 130-150 days averagely, containing 30$35 \%$ oil in its seeds, having summer characteristics, exhibiting various colored flowers such as yellow, red, orange, white and it can usually grow to $80-100 \mathrm{~cm}$ heights, and forms with and without pricks can be found [24].

Safflower having more tolerance against cold and drought comparing to other summer time oily plants is one of the plants that should be seriously considered for compensating 
our herbal oil deficit as it can be an important alternative, especially in arid agricultural fields [20].

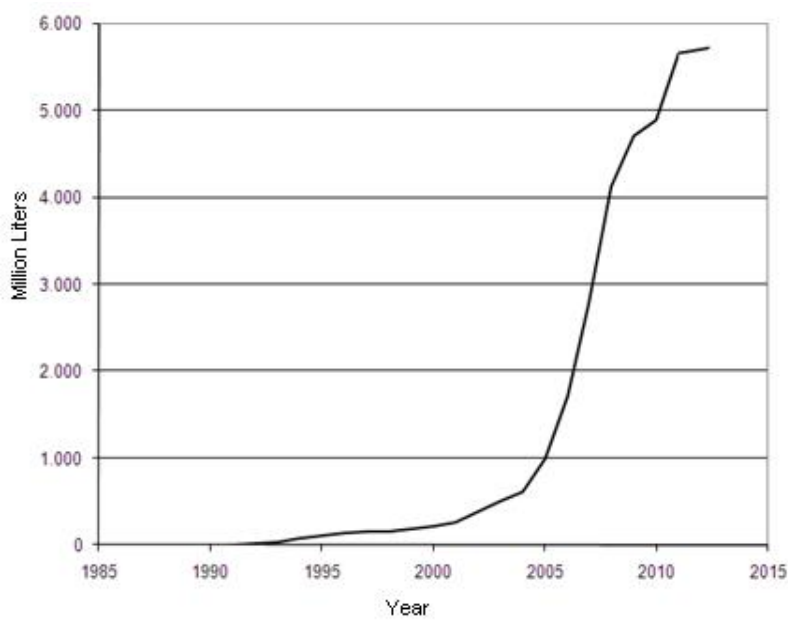

Fig.5. World biodiesel production [4]

The most obvious property of safflower oil is low saturated fatty acid ratio and high unsaturated fatty acids ratio. It has very low linoleic fatty acid or no linoleic fatty acid in its fatty acid composition so no dark colors can be observed. With this feature, it is consumed as margarine, salad and mayonnaise oil in western countries. Safflower oil regarded as in half drying oil group is also utilized in varnish, paint, polish and soap production [23].

Total cultivation area of safflower of Compositeae family (Carthamustinctorius L.) is 1.121 .212 ha. India comes first with its 700.000 ha area and 400.000 tons production and it supplies $70 \%$ of world safflower production. USA, Mexico and China follow India regarding their capacities [17].

Comparison of safflower types cultivated in Turkey is given in table 1 .

TABLE 1. Comparison of safflower types cultivated in Turkey [25][6][7]

\begin{tabular}{|c|c|c|c|c|c|c|}
\hline $\begin{array}{l}\text { Safflower } \\
\text { Species }\end{array}$ & Barbed & $\begin{array}{l}\text { Flowers } \\
\text { Color }\end{array}$ & $\begin{array}{c}\text { Plant } \\
\text { Length } \\
(\mathrm{cm})\end{array}$ & $\begin{array}{l}\text { Seed } \\
\text { color }\end{array}$ & $\begin{array}{l}\text { Oil Rate } \\
(\%)\end{array}$ & $\begin{array}{c}1000 \\
\text { weight } \\
(\mathrm{g})\end{array}$ \\
\hline Yenice & Barbless & Red & $100-120$ & White & $24-25$ & $38-40$ \\
\hline Dinçer & Barbless & Orange & $90-110$ & White & $25-28$ & $45-49$ \\
\hline $\begin{array}{c}\text { Remzibey } \\
05\end{array}$ & Barbed & Yellow & $60-80$ & White & $35-40$ & $46-50$ \\
\hline Balc1 & Barbed & Yellow & $55-70$ & Cream & $38-40$ & $40-48$ \\
\hline Linas & Barbed & Orange & $85-90$ & Cream & $39-41$ & $38-42$ \\
\hline Ayaz & $\begin{array}{l}\text { Barbed } \\
\text { Less }\end{array}$ & Orange & $90-120$ & White & $22-26$ & $40-44$ \\
\hline
\end{tabular}

\section{MATERIAL AND METHODS}

The methyl alcohol used for biodiesel production from safflower oil in the present study has the chemical formulation of $\mathrm{CH}_{3} \mathrm{OH}$ and it has Merck brand name. The density of the used methyl alcohol is $0.791-0.793 \mathrm{~kg} / \mathrm{l}$ at $20^{\circ} \mathrm{C}$ and its molecular mass is $32.04 \mathrm{~g} / \mathrm{mol}$ (Figure 6).

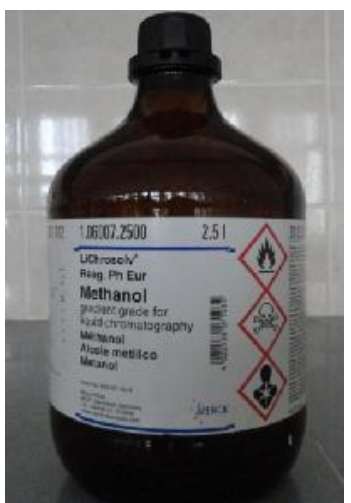

Fig. 6 Alcohol utilized in safflower biodiesel production [8]

In the safflower biodiesel production, sodium hydroxide $(\mathrm{NaOH})$ having $40 \mathrm{~g} / \mathrm{mol}$ molecular mass, a greater purity than $97 \%$ and Merck brand name was used as catalyst (Figure 7).

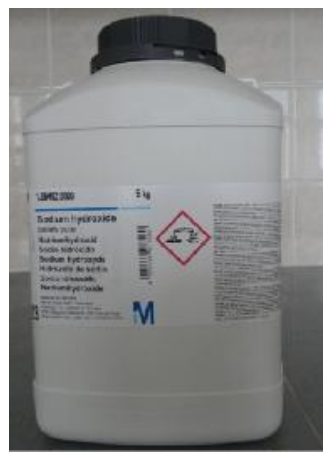

Fig. 7 Catalyst used in safflower biodiesel production [8]

Molasses originating bioethanol that was used in the experiments was supplied by "Konya Şeker Sanayi veTicaret A.Ş." company at 15.08.2012 date. The bioethanol was $99.8 \%$ pure. Its chemical formulation is $\mathrm{C}_{2} \mathrm{H}_{5} \mathrm{OH}$. Breathing or swallowing the bioethanol is very dangerous. It must be avoided from contacting to eyes or skin. It should be kept in a cool environment, away from oxidizing materials. Flow scheme of bioethanol process is seen in figure 8 .

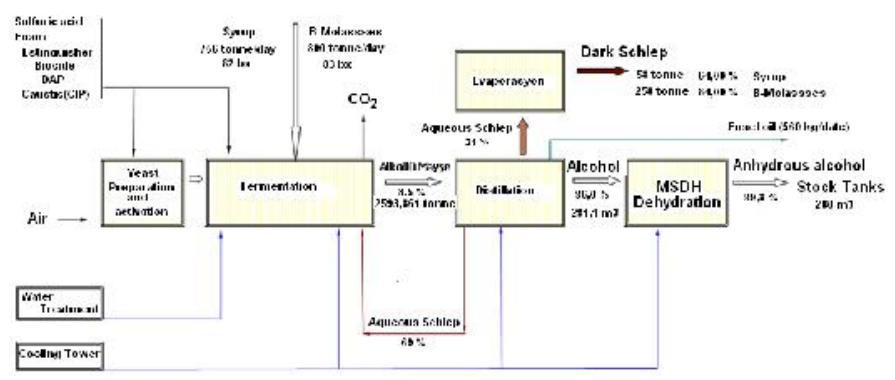

Fig.8 Bioethanol production process from molasses [1]

Biodiesel production facility in Selcuk University, Faculty of Agriculture, Biodiesel Laboratory has a capacity of 100 liter biodiesel production per hour. The facility can be operated both by manually or by automation systems. 
With the automation system, production can be completed without any further interference after necessary materials are placed in raw oil tank, catalyst tank and methanol tank (Figure 9).



Fig. 9 Biodiesel production and programmable logic controller (PLC)facility [8]

Present study was performed in six steps as explained below.

- Acquisition of safflower seed,

- Safflower oil extraction from safflower seed,

- Production of safflower oil methyl ester (SOME) which will be used as an alternative fuel in engines,

- Bioethanol procurement and preparation

- Preperation of $\mathrm{M}_{100}, \quad \mathrm{E}_{2.5} \mathrm{~B}_{2.5} \mathrm{M}_{95}, \quad \mathrm{E}_{5} \mathrm{~B}_{5} \mathrm{M}_{90}$, $\mathrm{E}_{5} \mathrm{~B}_{2.5} \mathrm{M}_{92.5}$ and $\mathrm{E}_{2.5} \mathrm{~B}_{5} \mathrm{M}_{92.5}$ fuel mixtures,

- Determination of properties of $\mathrm{M}_{100}, \mathrm{E}_{2.5} \mathrm{~B}_{2.5} \mathrm{M}_{95}$, $\mathrm{E}_{5} \mathrm{~B}_{5} \mathrm{M}_{90}, \mathrm{E}_{5} \mathrm{~B}_{2.5} \mathrm{M}_{92.5}$ ve $\mathrm{E}_{2.5} \mathrm{~B}_{5} \mathrm{M}_{92.5}$ fuel mixtures.

Although there are different methods for biodiesel production, the most widespread method today is transesterification. This method is a process in which herbal oils are reacted with alcohol with the help of a catalyst and reesterification of the oils. Recently, this method is the most effective one in decreasing viscosity [23].

Samples tested during experiments were prepared according to volumetric ratio basis. Mixtures were tried to be homogenous by mixing them both in a laboratory type mixer at $1500 \mathrm{~min}^{-1}$ and in a homogenizer at $24000 \mathrm{~min}^{-1}$ each for 7.5 minutes, totally 15 minutes. No separation was observed after mixing process. Five different fuels were created via diesel, safflower biodiesel and bioethanol mixtures. $100 \%$ diesel is denoted as $\mathrm{M}_{100}$, the fuel that was formed with $2.5 \%$ volumetric bioethanol and $2.5 \%$ volumetric safflower biodiesel along with diesel fuel was denoted as $\mathrm{E}_{2.5} \mathrm{~B}_{2.5} \mathrm{M}_{95}$, the fuel that was formed with $5 \%$ volumetric bioethanol and $5 \%$ volumetric safflower biodiesel along with diesel fuel was denoted as $\mathrm{E}_{5} \mathrm{~B}_{5} \mathrm{M}_{90}$, the fuel that was formed with $5 \%$ volumetric bioethanol and $2.5 \%$ volumetric safflower biodiesel along with diesel fuel was denoted as $\mathrm{E}_{5} \mathrm{~B}_{2.5} \mathrm{M}_{92.5}$, the fuel that was formed with $2.5 \%$ volumetric bioethanol and $5 \%$ volumetric safflower biodiesel along with diesel fuel was denoted as $\mathrm{E}_{2.5} \mathrm{~B}_{5} \mathrm{M}_{92.5}$. Names of the fuels and their volumetric constitution percentages were given in table 2 [8].

TABLE 2. Names of the fuels and their volumetric constitution percentages [8].

\begin{tabular}{cccc}
\hline Fuels & DieselFuel & Bioethanol & Biodiesel \\
\hline $\mathrm{M}_{100}$ & 100 & 0 & 0 \\
$\mathrm{E}_{2.5} \mathrm{~B}_{2.5} \mathrm{M}_{95}$ & 95 & 2.5 & 2.5 \\
$\mathrm{E}_{5} \mathrm{~B}_{5} \mathrm{M}_{90}$ & 90 & 5 & 5 \\
$\mathrm{E}_{5} \mathrm{~B}_{2.5} \mathrm{M}_{92.5}$ & 92.5 & 5 & 2.5 \\
$\mathrm{E}_{2.5} \mathrm{~B}_{5} \mathrm{M}_{92.5}$ & 92.5 & 2.5 & 5 \\
\hline
\end{tabular}

Prepared fuel samples are seen in figure 10.

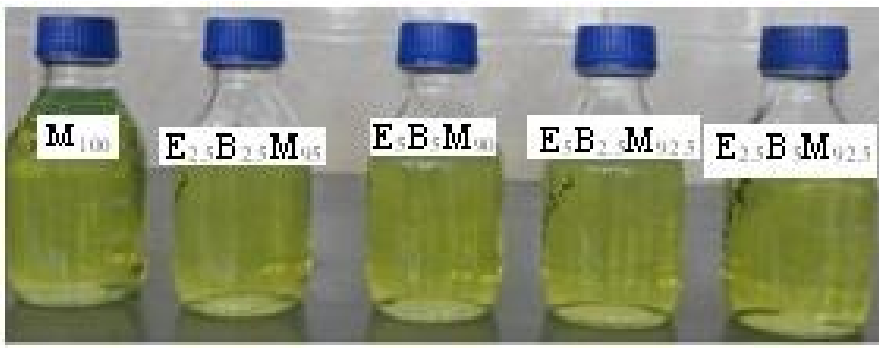

Fig. 10 Fuel samples $[8]$

Analyses results are seen in table 3 . Standard values in the table are from TS EN 590 for diesel fuel and TS EN 14214 for biodiesel.

\section{CONCLUSIONS}

In this study, $\mathrm{M}_{100}, \mathrm{E}_{2.5} \mathrm{~B}_{2.5} \mathrm{M}_{95}, \mathrm{E}_{5} \mathrm{~B}_{5} \mathrm{M}_{90}, \mathrm{E}_{5} \mathrm{~B}_{2.5} \mathrm{M}_{92.5}$ and $\mathrm{E}_{2.5} \mathrm{~B}_{5} \mathrm{M}_{92.5}$ fuel mixtures were used. These fuel mixtures were obtained by mixing biodiesel fuel obtained from safflower by means of transesterification with diesel fuel at a biodiesel to diesel volumetric ratio of $2.5 \%$ and $5 \%$ and bioethanol additives at a ratio of $2.5 \%$ and $5 \%$.

Decreasing the viscosity of the biodiesel fuel and improving its convenience as a diesel fuel were achieved by mixing high viscosity biodiesel with diesel and bioethanol. Diesel fuel cetane number was increased by means of the mixture and it was seen that the fuel properties of ethanolbiodiesel-diesel mixtures are in the range of the standards. 
TABLE 3. Analyses results of the fuels [8]

\begin{tabular}{|c|c|c|c|c|c|c|c|c|c|c|c|}
\hline \multirow{2}{*}{$\begin{array}{c}\text { Characteristic } \\
\text { Properties }\end{array}$} & \multirow{2}{*}{ Units } & \multirow{2}{*}{$\begin{array}{c}\text { Raw } \\
\text { Safflower } \\
\text { Oil }\end{array}$} & \multirow{2}{*}{$\begin{array}{l}\text { Safflower } \\
\text { Biodiesel }\end{array}$} & \multirow{2}{*}{$\mathrm{M}_{100}$} & \multirow{2}{*}{$\begin{array}{c}\mathrm{E}_{2.5} \mathrm{~B}_{2 .} \\
{ }_{5} \mathrm{M}_{95}\end{array}$} & \multirow{2}{*}{$\begin{array}{c}\mathrm{E}_{5} \mathrm{~B}_{5} \\
\mathrm{M}_{90}\end{array}$} & \multirow{2}{*}{$\begin{array}{c}\mathrm{E}_{5} \mathrm{~B}_{2.5} \\
\mathrm{M}_{92.5}\end{array}$} & \multirow{2}{*}{$\begin{array}{c}\mathrm{E}_{2.5} \mathrm{~B}_{5} \\
\mathrm{M}_{92.5}\end{array}$} & \multirow{2}{*}{$\begin{array}{l}\text { Bio } \\
\text { ethanol }\end{array}$} & \multicolumn{2}{|c|}{ Limiting Values } \\
\hline & & & & & & & & & & $\begin{array}{c}\text { Diesel } \\
\text { Fuel }\end{array}$ & $\begin{array}{c}\text { Bio } \\
\text { diesel }\end{array}$ \\
\hline Density $\left(15^{0} \mathrm{C}\right)$ & $\mathrm{g} / \mathrm{cm}^{3}$ & 0,92 & 0,88 & 0,83 & 0,83 & 0,83 & 0,83 & 0,83 & 0,79 & $\begin{array}{c}0.82- \\
0.84\end{array}$ & $\begin{array}{c}0.86- \\
0.90\end{array}$ \\
\hline $\begin{array}{l}\text { Kinematic } \\
\text { Viscosity } \\
\left(40^{\circ} \mathrm{C}\right)\end{array}$ & $\mathrm{mm}^{2} / \mathrm{s}$ & 31,23 & 4,32 & 3,35 & 2,69 & 2,63 & 2,56 & 2,66 & 1,27 & $2-4.5$ & $3.5-5$ \\
\hline Flash Point & ${ }^{0} \mathrm{C}$ & 170 & 121 & 60 & - & - & - & - & - & 55 & 101 \\
\hline Water Content & ppm & 20,18 & 393 & 33,51 & 78,84 & 75,42 & 89,67 & 83,63 & 372,8 & 200 & 500 \\
\hline $\mathrm{pH}$ & - & 4,8 & 5 & 5 & 5 & 5 & 5 & 5 & 5 & - & - \\
\hline $\begin{array}{c}\text { Color } \\
\text { Determination }\end{array}$ & ASTM & 2,3 & 1,4 & 1,2 & 1,2 & 1,2 & 1,2 & 1,2 & $<0,5$ & - & - \\
\hline Calorific Value & $\mathrm{kJ} / \mathrm{kg}$ & 5897 & 40801 & 47628 & 47389 & 46239 & 47504 & 46718 & 29594 & - & - \\
\hline $\begin{array}{l}\text { Cloud } \\
\text { Point }\end{array}$ & ${ }^{0} \mathrm{C}$ & -1 & -2 & -9 & $-8,1$ & $-6,4$ & -6 & $-6,2$ & - & - & - \\
\hline $\begin{array}{l}\text { Pour } \\
\text { Point }\end{array}$ & ${ }^{0} \mathrm{C}$ & -15 & $-7,5$ & -20 & $-12,3$ & $-11,2$ & $-11,1$ & $-10,5$ & - & - & - \\
\hline Freezing Point & ${ }^{0} \mathrm{C}$ & $<-20$ & $-13,4$ & $<-20$ & $<-20$ & $<-20$ & $<-20$ & $<-20$ & $<-20$ & - & - \\
\hline CFPP & ${ }^{0} \mathrm{C}$ & - & -6 & -19 & -18 & -18 & -17 & -18 & $<-50$ & -20 & -15 \\
\hline $\begin{array}{l}\text { Copper Strip } \\
\text { Corrosion }\end{array}$ & - & $1 \mathrm{a}$ & $1 \mathrm{a}$ & $1 \mathrm{a}$ & $1 \mathrm{a}$ & $1 \mathrm{a}$ & $1 \mathrm{a}$ & $1 \mathrm{a}$ & $1 \mathrm{a}$ & No:1 & No: 1 \\
\hline Iodine value & $\begin{array}{l}\text { giyot/ } \\
100 \mathrm{~g}\end{array}$ & 117,9 & 117,9 & - & - & $\longrightarrow$ & - & - & 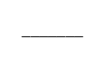 & - & - \\
\hline Cetane Number & - & 45,27 & 41,92 & 54,84 & 57,28 & 56,26 & 55,99 & 57,50 & - & 51 & - \\
\hline
\end{tabular}

\section{ACKNOWLEDGMENT}

The authors acknowledge the financial support provided by Scientific Research Projects Coordinatorship of Selcuk University Contract No: 14701647 . This study is prepared as a part of Fatih AYDIN's Ph.D. thesis.

\section{REFERENCES}

[1] Anonymous, 2012, Konya Şeker Industry and Trade Co, Ltd. Çumra Şeker Bioethanol Factories Production Proses Booklet, Konya.

[2] Anonymous, 2013 a, World Fuel Ethanol Production [online], http://www.earth-policy.org/search?q=bioethanol, Date of Visit: [05.12.2013].

[3] Anonymous, 2013 b, Republic of Turkey Ministry of Energy and Natural Resources, General Directorate of Renewable Energy[online],http://www.eie.gov.tr/yenilenebilir/biyodizel.aspx, Date of Visit: [12.12.2013].

[4] Anonymous, 2014 a, World Fuel Ethanol Production [online],http://www.earth-policy.org/search?q=biodiesel, Date of Visit: [15.01.2014].

[5] Anonymous, 2014 b, Alternative Energy and Biodiesel Producers Association [online], http://www.albiyobir.org.tr/dunyada b.htm, Date of Visit: [16.01.2014]

[6] Anonymous, 2014 c, Directorate of Trakya Agricultural Research Institute [online],http://www.ttae.gov.tr/index.php/uruncesitleri/aspir/linas, Date of Visit: [04.02.2014].
[7] Anonymous, 2014 d, Bahri Dağdaş International Agricultural Research Institute [online],http://www.bahridagdas.gov.tr/duyuru, Date of Visit: [04.02.2014]

[8] Aydın, F., 2014, Effects of using e-b diesel fuel in single cylinder diesel engine to engine performance, Emissions And Lubrication Oil, Ph.D. thesis, The Graduate School Of Natural And Applied Science Of Selcuk University, Konya.

[9] Balat, B., Balat, H. and Öz, C., 2008, Progress in bioethanol processing, Progress In Energy And Combustion Science, 34, 551-573.

[10] Barabas, I.,Todorut, A. and Baldean, D., 2010, Performance and emission characteristics of an c1 engine fueled with diesel-biodieselbioethanol blends, Fuel, 89, 3827-3832.

[11] Bulut, B., 2006, From alternative fuel resources agriculture based bioethanol and bioethanol raw choosing the most suitable for Turkey, Master Thesis, The Graduate School Of Natural And Applied Science Of Yildiz Technical University, stanbul, 12-50.

[12] Hansen, A. C., Zhang, Q. and Lyne, P. W. L., 2005, Ethanol-diesel fuel blends - a review, Bioresource Technology, 96, (3): 277-285.

[13] şler, A., 2007, Canola Oil Ethyl Ester and E-Dizel, Master Thesis, Graduate School Of Science, Engineering and Technology stanbul Technical University, stanbul, 20-29.

[14] Jitputti, J.,Kitiyanan, B., Rangsunvigit, P., Bunyakiat, K., Attanatho, L. and P., Jenvanitpanjakul, 2006, Transesterification of crude palm kernel oil and crude coconut oil by different solid catalysts, Chemical Engineering Journal, Volume 116, Issue 1, Pages 61-66. 
[15] Karaosmanoğlu, F., 2002, For Turkey eco-friendly - biodiesel is a renewable fuel candidate, Ecogeneration World-Journal of Cogeneration, stanbul, 10 (1), 50-56.

[16] Karthikeyan, B. and Srithar, K., 2011, Performance characteristics of a glow plug assisted low heat rejection diesel engine using ethanol, Applied Energy, 88, 323-329.

[17] Katmer, E., Derici, O., Çelikoğlu, F., Erbahadır, M. A. and Balcı, A. 2005, Produced in our country safflower oil plant derived from edible determination of quality characteristics and storage conditions, Republic of Turkey Ministry of Food, Agriculture and Livestock, General Directorate of Agricultural Researches and Policies, Food Control and Central Research Institute.. Project Code No: TAGEM/GY/02/11/08/069, Genel Yayın No:127, Bursa.

[18] Knothe, G., 2001, Historical perspective on vegetable oil-based diesel fuels, Inform, 12 (11), 1103-1107.

[19] Koçtürk, D., 2011, The assessment of economic and environmental aspect of spark ignition engines fuelled by different characteristic ethanol - gasoline blends, Ph.D. thesis, Ankara University Graduate School of Natural and Applied Sciences, Ankara, 1-54.

[20] Kolsarıcı, Ö., Gür, A., Başalma, D., Kaya, M.D. ve sler, N., 2005, Oil seed plants production, TMMOB (the UNION of the Chambers of Turkish Engineers and Architects) the Chamber of Agricultural Engineers Turkey Agricultural Engineering VI. Technical Congress, Ankara.

[21] Niyet, M., 2009, Investigating the effect of biodiesel usage on the engine wear in diesel engines, Master Thesis, Dumlupınar University Graduate School of Natural and Applied Sciences, Kütahya, 15-16.

[22] Öğüt, H., Eryılmaz, T., Akınerdem, F. ve Oğuz, H., 2005, Agricultural sources biofuels (bioethanol and biodiesel), Journal of Trade Exchanges, Konya, 8(19), 26-29.

[23] Öğüt, H. and Oğuz, H., 2006, Third of the millennium biodiesel fuel, Nobel Yayın Dă̆ıtım, Second Edition, ISBN 975-591-730-6, Konya.

[24] Öğüt, H., Eryılmaz, T. and Oğuz, H., 2007, Some of safflower (carthamustinctorius 1.) type of biodiesel produced from the comparative analysis of fuel properties, 1. National Oil and Biodiesel Plants Seeds Symposium, Samsun.

[25] Öğüt, H., Oğuz, H., Bacak, S., Menges, H.O., Köse, A. and Eryılmaz, T., 2012, Investigation of the characteristics of biodiesel from balc1 species of safflower, Journal Of Agricultural Machinery Science, 8 (3), 297-300.

[26] Pamir, N., 2003, Energy in the World and in Turkey, Turkey's energy resources and energy policies, Journal of Metallurgy, 134, 2-4.

[27] Utlu, Z., 2003, Analysis of Turkey's sectoral energy and exergy utilization efficiency by 2023, Ph.D. thesis, Ege University Graduate School of Natural and Applied Sciences, zmir, 10. 